\title{
Effects of Heavy Metal Lead (Pb) Exposure on Chlorophyll Content and Anatomic Structure of rice (Oryza sativa L.)
}

\author{
Supriatno, Chairunnisa, Hafnati Rahmatan \\ Department of Biology Education, Faculty of Teacher Training and Education. \\ Syiah Kuala University, Banda Aceh, Indonesia \\ \{supriatno@gmail.com\}
}

\begin{abstract}
Lead $(\mathrm{Pb})$ is one of the heavy metals that have received considerable attention as a poisonous pollutant and has a bad effect on living things, one of them on plants, especially food crops such as rice (Oryza sativa L.). Lead exposure has been shown affected by rice plant growth, but require further testing of the anatomy. This research was conducted with the aim to know the effects of heavy metal lead $(\mathrm{Pb})$ on the chlorophyll and anatomy of rice, especially the anatomy of roots and leaves. The rice variety used is Inpari-32. This research type is experimental, with a qualitative and quantitative approach. The experimental design used in this study was Completely Randomized Design (CRD) which consisted of three treatments variations with nine replications. Chlorophyll content was analyzed by ANOVA test while root and leaf anatomy was done descriptively. From the measurement result using a spectrophotometer, it showed significant differences for chlorophyll content in each treatment, where the average result of chlorophyll analysis from the three treatments was $39.31 \mathrm{mg} / \mathrm{L}$ (P0), $16.294 \mathrm{mg} / \mathrm{L}$ (P1), and $10.815 \mathrm{mg} / \mathrm{L}$ (P2). From the analysis, it has been known that the values Fvalue $>$ Ftable $(27.798 .532,356>3,40)$, it can be concluded that lead exposure effects total chlorophyll content and caused anatomic structures to change of the roots and leaves of rice.
\end{abstract}

Keywords: Lead (Pb), Oryza sativa L., Root and leaf anatomy, Chlorophyll content

\section{INTRODUCTION}

Pollution caused by heavy metals is an issue against the current environmental conditions. Among the many heavy metals, such as lead $(\mathrm{Pb})$, mercury $(\mathrm{Hg})$, cadmium $(\mathrm{Cd})$ is widely known as the most toxic to the environment. These metals get into an environment where they are produced, used, and finally discarded. Highly toxic heavy metals, such as ions or compounds form, they are water soluble and easily absorbed into living organisms. Once absorbed, these metals can bind to cellular components such as proteins vital structural, enzymes, nucleic acids, This can interfere with the function/activity of the component [1].

Lead $(\mathrm{Pb})$ is a metal that is widely known by the public. $\mathrm{Pb}$ is a type of metal that is malleable and blackish-brown. The danger posed by the use of $\mathrm{Pb}$ is a frequent cause of poisoning. $\mathrm{Pb}$ metal widely used in industrial batteries, wiring, paint, gilding, pesticides, also as the substance in gasoline [2]. 
Lead pollution is generally derived from human activities that use the metal, as expressed by Amaliah [3] where the source of the pollution of lead $(\mathrm{Pb})$ from the largest man-made, namely gasoline made from a mixture of lead to materials motor vehicle fuel. In addition, having a bad influence on humans, lead exposure can also effect badly against the surrounding environment in a wide range, including agricultural land adjacent to the road. Indirectly the agricultural land located at the roadside can accumulate $\mathrm{Pb}$ from waste air emissions of motor vehicles.

The distance between agricultural land and road may affect the levels of lead in the soil, the statement is supported by the results of research that have been done by Nurmalia[4] about the content of heavy metals lead $(\mathrm{Pb})$ in the soil of paddy fields surrounding the highway Banda Aceh-Medan in Indrapuri subdistrict of Reukih Village, Aceh Besar Regency. Sampling is done at a distance of 50-300 $\mathrm{m}$ from the highway. The results showed that the highest lead levels found in a rice field at a distance of $50 \mathrm{~m}$ from the highway, $0.059 \mathrm{ppm}$. Although the levels are still in the category currently, but now with a volume of vehicles continues to increase, it cannot be denied that the impact of lead pollution against the agricultural land located on the side of the road is getting high. With the presence of heavy metals in soils implies absorbed into plant tissue, especially when heavy metals are present in the dissolved form if the plant that binds are food crops like rice then heavy metal pollution would be more dangerous to humans [5].

Rice plant can absorb lead not only from the air. Other means of contamination of lead can pass through water used for agricultural activities, metal concentrations can be affected by the influx of wastewater containing heavy metals such as industrial and domestic wastes into the waters with the help of rain, river water, and the wind [6]. Based on research conducted by Amelia, Rachmadiarti, \& Yuliani [7] concerning the analysis of heavy metals $\mathrm{Pb}$ against the rice, lead which comes from water and polluted substrate have a positive effect against rice growth include high, number of leaves and its biomass. Plants that are exposed by lead can change in growth, development, morphology, anatomy, and physiology [8].

In this issue is needed for further research concerning the physiology and anatomy of rice exposed by the heavy metals lead $(\mathrm{Pb})$. Therefore, research is carried out with the purpose to know the effects of lead exposure on chlorophyll content and anatomic structure of rice (Oryza sativa L.)

\section{Method}

\subsection{Place and Time}

This research was conducted in the biology laboratory of Mathematics and Natural Sciences Faculty and the laboratory of Biology Education Faculty of Teacher Training and Educational Sciences Syiah Kuala University, Banda Aceh. This research took place from April until July 2018.

\subsection{Research Procedure}

The variety used in this research is Inpari-32. Rice cultivation using hydroponic techniques for 36 days. There are three types of treatment with nine replicates. As treatment, time variations of lead in the form of $\mathrm{Pb}\left(\mathrm{NO}_{3}\right)_{2}$ with its concentration is $1000 \mathrm{ppm}$, where the first treatment without any given $\mathrm{Pb}$ (controls), at the second treatment is given from the initial $\mathrm{Pb}$ nursery, then the third treatments are given $\mathrm{Pb}$ right at the moment the seedlings were transferred into 
the tub ( 10 day old seedlings). Each media contains 10 rice seeds. The degree of acidity (pH) of nutrient solution used worth 6 , can be observed by using a $\mathrm{pH}$ meter.

There are two parameters to be analyzed, chlorophyll content and the anatomy of rice (root and leaf). Analysis of chlorophyll content done by taking 1 gram of sample from each treatment, then put into a mortal and then crushed, added $20 \mathrm{~mL}$ alcohol $96 \%$. The aqueous extract is filtered using the filter paper, then poured into a tube and after that its absorbance is measured by using a spectrophotometer at a wavelength of $649 \mathrm{~nm}$ and $665 \mathrm{~nm}$. Total chlorophyll content $(\mathrm{mg} / \mathrm{L})$ is determined using the equations according to Wintermans \& De Mots [9] in Larasati [10]:

$\mathrm{Chl}_{\text {total }}=20,0 . \mathrm{A} 649+6,10 \cdot \mathrm{A} 665$

Description:

$\mathrm{Chl}_{\text {total }}$ : Total chlorophyll

A665: Absorbance at $665 \mathrm{~nm}$ wavelength.

A649: Absorbance at $649 \mathrm{~nm}$ wavelength.

Anatomical observation of rice plant using permanent preparations made with paraffin method by Sass [11] with little modification. As a sample, the plant is taken from each treatment then separated the roots and leaves, soaked in a solution of fixative (FAA) for 24 hours. The sample then is dehydrated using alcohol with stratified concentrations. The next stage, namely the initial treatment using a solution of alcohol-xylol gradually up to pure xylol. After that continued with the process of infiltration using paraffin gradually, and then carried out the process of planting preparations (embedding). Preparations using a microtome slashed with a thickness of $20 \mu \mathrm{m}$, and then colored and observed using a microscope.

\section{Results and Discussion}

\subsection{Results}

\section{Chlorophyll Content}

The average result of chlorophyll content from three treatments showed significant differences. Chlorophyll for each treatment P0, P1 and P2 in sequence is $39.831 \mathrm{mg} / \mathrm{L}, 16.294$ $\mathrm{mg} / \mathrm{L}$ and $\mathrm{mg} / \mathrm{L}$ 10.815. Data then tested using the variant analysis (ANOVA) (Table 1).

Table 1. Variants Analysis Against Chlorophyll Content of Rice (Oryza sativa L.).

\begin{tabular}{cccccc}
\hline $\begin{array}{c}\text { Source } \\
\text { Diversity }\end{array}$ & $\begin{array}{c}\text { The Degree } \\
\text { of Freedom } \\
\text { (DF) }\end{array}$ & $\begin{array}{c}\text { The Sum of } \\
\text { Squares } \\
\text { (SS) }\end{array}$ & Central Square & F $_{\text {value }}$ & $\mathrm{F}_{\text {table }}(0.05)$ \\
\hline Treatment & 2 & 4277,890 & $2.138,945$ & $27.798 .532,356^{*}$ & 3,40 \\
Error & 24 & 0,002 & 0,0000769 & & \\
\hline Total & 26 & $4.277,892$ & & &
\end{tabular}

* Real different in level test 0.05 
The results of the analysis of variants against rice leaf chlorophyll content showed $\mathrm{F}_{\text {value }}>$ $\mathrm{F}_{\text {table }}(27798532.356>3.40)$ (Table 1$)$, it may be stated H0 is rejected at the 0,05 level test and $\mathrm{H} 1$ received with real. Therefore, it can be concluded that heavy metals lead $(\mathrm{Pb})$ exposure effect on total chlorophyll of rice. Further trials are needed to know of any differences between the treatments. Advanced test selection based on the current value of the diversity of coefficient (DIVC). The value of DIVC is $0.04 \%(<5 \%)$, the next test should be used is Honestly Significance Difference (HSD). HSD test results presented in Table 2.

Table 2. HSD Test Results Against lead (Pb) Effect on Chlorophyll of Rice (Oryza sativa L.).

\begin{tabular}{ccc}
\hline Treatment & Chlorophyll Content + HSD & Distance Limit \\
\hline P2 & $10,815+0,010$ & $10,825^{\mathrm{a}}$ \\
P1 & $16,294+0,010$ & $16,304^{\mathrm{b}}$ \\
P0 & $39,831+0,010$ & $39,841^{\mathrm{c}}$
\end{tabular}

Description: the numbers followed by a letter and in the same column means the different unreal.

Based on Table 2 it can be noted that the average levels of the chlorophyll from three treatments showed significant differences. Most high chlorophyll content found in the control plants (P0), followed by $\mathrm{P} 1$ and $\mathrm{P} 2$ as.

\section{Anatomic structure of rice (Oryza sativa L.)}

On leaf and root tissue preparations observed indicates that there are differences in the anatomy of each treatment. Observations using a microscope with a magnification of 400 times can be seen in Figure 1 for the anatomy of root and Figure 2 for the anatomy of the leaf.

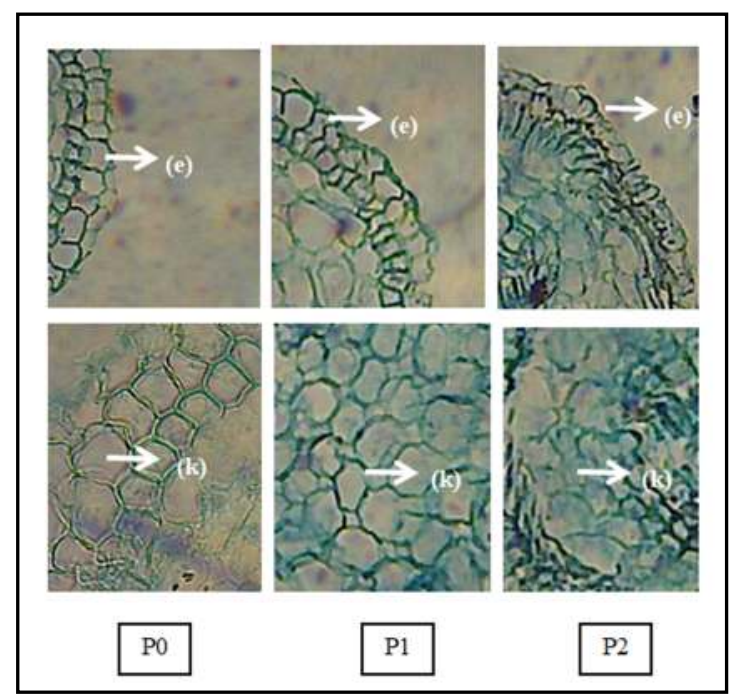

Figure 1. Cross Section Transverse Root Tissues of rice (Oryza sativa L.) (400x) (e: epidermis, $\mathrm{k}$ : cortex). 


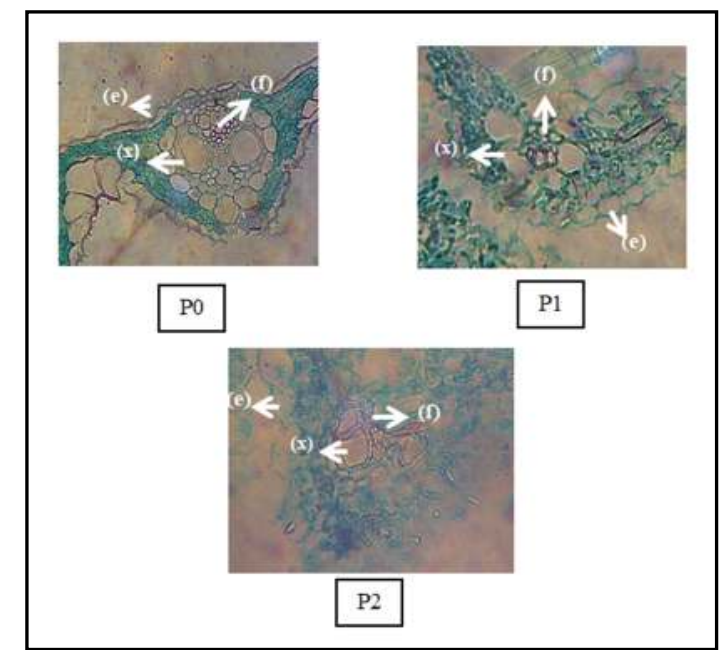

Figure 2. Cross Section Transverse Leaf Tissues of rice (Oryza sativa 1.) (400x), (f: phloem, x: xylem, e: the epidermis).

\section{Discussion}

\subsection{Effect of Lead on Chlorophyll Content}

Lead Exposure can affect the total chlorophyll of rice (Oryza sativa L.), total chlorophyll from three treatments showed that there is a difference. The longer the metal exposed by the plant, it will be increasingly reduced chlorophyll levels. That statement is supported by the results of research conducted by Puspita, Santoso, \& Yulianto [12] about the effects $\mathrm{Pb}$ towards the levels of chlorophyll in a plant leaf, where the result showed that the more higher concentration and the longer exposure of lead causes chlorophyll experienced a significant decline.

The high accumulation of lead is excessive intake of nutrients can reduce the $\mathrm{Fe}$ and $\mathrm{Mg}$ which resulted in changes in the number and volume of chloroplasts. Iron deficiency in plants resulting in the number and size of the grana of chloroplasts in being small, thus interrupting the formation of chlorophyll [13]. In addition to Fe and $\mathrm{Mg}$ concentrations, high lead also affects the availability of zinc $(\mathrm{Zn})$ in plants.

Porifirin ring is a component of chlorophyll. Precursors of the ring is a $\delta$-Aminolevulinat acid (ALA). The biosynthesis of the ALA can be done through two paths: (1) of suksinal-CoA and glycine, and (2) of glutamate. On the change of $\delta$-Aminolevulinic acid ( $\delta$-ALA) requires the enzyme Porphobilinogen into $\delta$-Aminolaevulinic acid dehydratase (ALAD). ALAD is the enzyme that has 8 identical subunits with one active site at each dimer. This enzyme binds $8 \mathrm{Zn}$ in each subunit. There is 4 Molecular Zink serves as the tertiary structure of the ALAD enzyme stabilizers, while 4 other Zink molecule serves as a catalyst. Lead inhibits the activity of the enzyme with changing the positions of in active site of the ALAD enzyme [14].

Iron $(\mathrm{Fe})$ plays an important role in the process of chlorophyll synthesis. A precursor of chlorophyll synthesis is blocked under the condition of Fe deficiency, which can cause a decrease in the concentration of chlorophyll. Fe is an important cofactor of numerous enzymes 
involved in the biosynthesis pathway of chlorophyll [15]. Conversion of Mg-protoporphyrin monomethyl ester (MgPMME) became Protochlorophyllide (Pchlide) through the three stages of oxidation, where two electrons in each phase of its use. At this stage, the electron, the electron donating Fe derived from changes to Fe3+ into Fe2+ [16]. Magnesium $(\mathrm{Mg})$ is the central atom of chlorophyll structure. In case of deficiency against three of metal, then the plant can not do the series of chlorophyll biosynthesis, chlorophyll which ultimately will not be formed.

Lead is more reactive than $\mathrm{Zn}, \mathrm{Fe}$, and $\mathrm{Mg}$. On the other hand, these elements can be easily replaced with lead. Therefore with the absorption of lead in small quantities-also can replace the elements needed in the biosynthesis of chlorophyll, so it resulted in decreased pigment in the leaves of plants, yellowing leaves are finally experiencing chlorosis.

\subsection{Effect of Lead on Root and Leaf Structure}

Plants can absorb lead upon the condition of fertility and low soil organic matter content. In this situation of heavy metals $\mathrm{Pb}$ will be detached from the bonds of the soil and the form of non-moving ions in the soil solution. If other metals are not capable of inhibiting its existence, then it will happen absorption lead by plant roots [17].

When heavy metals enter the cell, even in a matter of minutes, the metal will produce the effect of toxins on many processes: inhibit enzyme activity, largely interfere with the absorption of nutrients, disrupt hormonal work. These disorders can affect physiology and many activities in high concentrations can lead to cell death. Effects of heavy metals arising due to bind with protein functional groups, particularly groups of enzymes- $\mathrm{SH}$, lead can be easily bound to the cluster sulfihidrit (-SH) [18].

If the work of enzymes is compromised, then the hormone's work will work uninterrupted. Hormones that play a role in the process of the formation of such cytokinin and auxin. Cytokinin plays a role in stimulating cell division whereas auxin that acts to push the enlargement of cells. Disruption of the work of the enzyme causes the hormone to suffered a second labor disruption in cell division and enlargement [19].

The root is the first organ that will absorb $\mathrm{Pb}$ before getting into other plant organs. Lead exposure in the early growth of the roots can affect hormone balance, which ultimately affects cell division causing changes in the number of cells in the tissues. Lead initially moving through the lines apoplast and follow the flow of the water until it reaches the endodermis. The movement of the lead in the root system is disturbed by the presence of a barrier from the root endodermis. Endodermis block translocations $\mathrm{Pb}$ into the center of the tissues with the Casparian strip and continued with the translocation line symplast. However, a high concentration of lead is able to destroy the physical barrier formed by the Casparian strip [20].

Thickening of the endodermis cells also become an adaptation for blocking $\mathrm{Pb}$ translocation into the stele tissue. According to Handayanto, Muddarisna, \& Fiqri [21], high Pb content can cause the formation of abnormal morphology in plants, such as the occurrence of irregular thickening of the radial on the roots, endodermis cell walls and the formation of lignin in the parenkim cortex.

Thickening of the walls of the epidermis is also one of the effects of lead absorption by cells. These statements are supported by Alves, de Jesus, de Almeida, Souza, \& Mangabeira [22] that the absorption of metals $\mathrm{Pb}$ by the roots can affect the thickness of the epidermis in plants. The higher the concentration and the longer exposure of lead will be even greater damage occurred. The lead was also influential on the leaf epidermis, according to Weryszko-Chmielewska \& Chwil [23] changes caused by lead on epidermis structure of leaves in the form of a reduction in the size of the cell. 
The other part that becomes a point of attention, namely the vessel tissues. The tissues can be seen clearly on the results of the transverse incision of the leaf. There are vessels the carrier xylem and phloem tissues. Xylem and phloem have different functions and specific. Xylem takes place in transport water and minerals from the soil through the roots, while the phloem in carries the results of photosynthesis to all the organs of the plant [24].

Xylem and phloem were instrumental in the process of transporting elements of lead from the outside into the organs of the plant. After the lead entered into the root, then the metal is transported over a tissues transport that is xylem, headed to the other plant organs, such as the leaves. According to Weryszko-Chmielewska \& Chwil [23], the effects of lead exposure towards the transport chain can be a vast reduction of xylem and phloem in the vascular tissue and also affects the diameter of the xylem vessels.

\section{Conclusion}

Based on the results of the research, to be drawn the conclusion that the difference between exposure to heavy metals lead $(\mathrm{Pb})$ effect on chlorophyll concentration of rice, the longer the plant exposed causes the low levels of chlorophyll. Metal exposure also effects on root and leaf anatomy of rice.

\section{REFERENCES}

[1] W. G. Landis and Y. Ming-Ho, Introduction to environmental toxicology: Impacts of chemicals upon ecological systems, 3rd ed. United States of America: CRC Press LLC, 2004.

[2] Sudaryono and J. P. Susanto, "Pengaruh pupuk hayati terhadap akumulasi timbal dari kompos sampah kota dalam jaringan tanaman padi," PANGAN, vol. 24, no. 1, pp. 2536, 2015.

[3] N. Amaliah, Penyehatan makanan dan minuman. Yogyakarta: Deepublish, 2017.

[4] Nurmalia, "Kandungan timbal $(\mathrm{Pb})$, tembaga $(\mathrm{Cu}), \mathrm{C}$-organik dan $\mathrm{pH}$ tanah sawah sekitar jalan raya Banda-Aceh di desa Reukih kecamatan Indra Puri kabupaten Aceh Besar," Universitas Syiah Kuala, 2007.

[5] S. S. Adji, "Rehabilitasi tanah sawah tercemar logam berat $\mathrm{Pb}$ dan $\mathrm{Cd}$ melalui fitoremidiasi," J. Mat. Sains, dan Teknol., vol. 6, no. 2, pp. 63-70, 2005.

[6] I. Al Husainy, D. Bakti, and R. Leidonald, "Analisis kandungan logam berat timbal (Pb) di air dan sedimen pada aliran sungai Percut provinsi Sumatera Utara," $J$. Aquacoastmarine, vol. 5, no. 4, pp. 20-30, 2014.

[7] R. A. Amelia, F. Rachmadiarti, and Yuliani, "Analisis kadar logam berat Pb dan pertumbuhan tanaman padi di area persawahan dusun Betas, desa Kapulungan, GempolPasuruan," LenteraBio, vol. 4, no. 3, pp. 187-191, 2015.

[8] D. Ariyanti, J. D. Budiono, and F. Rachmadiarti, "Analisis struktur daun sawi hijau (Brassica rapa var. Parachinensis) yang dipapar dengan Logam Berat Pb (Timbal)," Lentera Bio, vol. 31, no. 82, pp. 37-42, 2015.

[9] J. F. G. M. Wintermans and A. De Mots, "Spectrophotometric characteristics of chlorophylls a and b and their phenophytins in ethanol," Biochim. Biophys. Acta Biophys. Incl. Photosynth., vol. 109, no. 2, pp. 448-453, 1965.

[10] T. Larasati, "Kandungan klorofil daun pepaya betina (Carica papaya L.) pada beberapa posisi daun yang berbeda," Universitas Lampung, 2017.

[11] J. E. Sass, Botanical microtechnique, 3rd ed. Ames, Iowa; Orange St., London WC2: 
The Iowa State College Press; Constable \& Co., 1958.

[12] A. D. Puspita, A. Santoso, and B. Yulianto, "Studi akumulasi logam timbal (Pb) dan efeknya terhadap kandungan klorofil daun mangrove rhizophora mucronata," J. Mar. Res., vol. 3, no. 1, pp. 44-53, 2013.

[13] L. Advinda, Dasar-dasar fisologi tumbuhan. Yogyakarta: Penerbit Deepublish, 2018.

[14] R. S. Ajioka, J. D. Phillips, and J. P. Kushner, "Biosynthesis of heme in mammals," Biochim. Biophys. Acta - Mol. Cell Res., vol. 1763, no. 7, pp. 723-736, 2006.

[15] Q.-S. Wu, Ed., Arbuscular mycorrhizas and stress tolerance of plants. Gateway East, Singapore: Springer Nature Singapore Pte Ltd, 2017.

[16] V. Steccanella, M. Hansson, and P. E. Jensen, "Linking chlorophyll biosynthesis to a dynamic plastoquinone pool," Plant Physiol. Biochem., vol. 97, pp. 207-216, Dec. 2015.

[17] Widaningrum, Miskiyah, and Suismono, "Bahaya kontaminasi logam berat dalam sayuran dan alternatif pencegahan cemarannya," Bul. Teknol. Pascapanen Pertan., vol. 3, no. 1, pp. 16-27, 2007.

[18] I. V Seregin and V. B. Ivanov, "Physiological aspects of cadmium and lead toxic effects on higher plants," Russ. J. Plant Physiol., vol. 48, no. 4, pp. 523-544, 2001.

[19] A. Munawwaroh, "Pengaruh pemberian berbagai konsentrasi tembaga $(\mathrm{Cu})$ terhadap jumlah trakea akar eceng gondok (Eichhornia crassipes)," J. Yudharta, vol. 10, no. 2, pp. 1-8, 2016.

[20] P. Ahmad, Ed., Plant metal interaction Emerging remediation techniques. Netherlands: Elsevier, 2015

[21] E. Handayanto, N. Muddarisna, and A. Fiqri, Pengelolaan kesuburan tanah. Malang: Universitas Brawijaya Press, 2017.

[22] L. Q. Alves, R. M. de Jesus, A. A. F. de Almeida, V. L. Souza, and P. A. O. Mangabeira, "Effects of lead on anatomy, ultrastructure and concentration of nutrients in plants Oxycaryum cubense (Poep. \& Kunth) Palla: A species with phytoremediator potential in contaminated watersheds," Environ. Sci. Pollut. Res., vol. 21, no. 10, pp. 6558-6570, 2014.

[23] E. Weryszko-Chmielewska and M. Chwil, "Lead-induced histological and ultrastructural changes in the leaves of soybean (Glycine max (L.) Merr.)," Soil Sci. Plant Nutr., vol. 51, no. 2, pp. 203-212, Apr. 2005.

[24] F. Kurniawati, S. Zaenab, and S. Wahyuni, "Analisis perbandingan bentuk jaringan pembuluh trakea pada preparat maserasi berbagai genus piper sebagai sumber belajar biologi," Pendidik. Biol. Indones., vol. 1, no. 2, pp. 148-157, 2015. 